\title{
Etiopathology and Haematobiochemical Alteration in the Anaemic Dogs of in and Around Anand Region, Gujarat
}

\author{
Falguni Tandel*, Rajesh Jani, Avinash Bilwal and Prasann Vasava \\ Department of Veterinary Medicine, College of Veterinary Science and Animal Husbandry, Anand Agricultural University, \\ Anand, Gujarat, INDIA \\ "Corresponding author: FB Tandel; E-mail: tandelfalguni1890@gmail.com
}

Received: 01 Oct., 2019

Revised: 05 Nov., 2019

Accepted: 09 Nov., 2019

\begin{abstract}
The present research work was undertaken to assess the etiopathology and haematobiochemical alterations in anemic dogs of Anand region, Gujarat irrespective of their age, sex and breed. Total 78 dogs were screened for anemia and blood samples were collected from a 51 anemic dogs of Anand region of Gujarat to identify etiopathology and haematobiochemical parameters alterations. Statistical analysis, interpretation, different etiology and comparison of haematobiochemical alteration with scientific literature were carried out to understand pathophysiology of disease. Amongst 78 of $51 \mathrm{dogs}$, incidence of anemia was recoded 65.38 per cent in which highest was due to liver disorders $(23.53 \%)$. Incidence of anemia was observed higher in in adult group $(58.83 \%)$ as well as in male $(52.94 \%)$. Most clinical variants of anemic dogs showed pale mucous membrane (86.27\%), hypothermia (68.63\%), tachycardia (70.59\%), tachypnea $(74.51 \%)$ and increased capillary refilling time $(64.71 \%)$. Haematological indices of anemic dogs revealed Hb, TEC, PCV, MCH, MCHC and MCV decreased significantly $(p<0.01)$, whereas TLC increased significantly $(\mathrm{p}<0.05)$ as compare to healthy dogs. Serum biochemistry revealed significantly $(\mathrm{p}<0.01)$ increased BUN, Creatinine, Glucose, AST and ALT levels as well as decreased in total protein level in anemic case as compare to healthy ones. Different etiological factors for developing in anemia in dogs as well as hematobiochemical alterations are mentioned, which will be useful for further detailed investigations and therapeutic management.
\end{abstract}

Keywords: Anemia, Clinical signs, Dog, Etiology, Haematobiochemical changes

Anemia is commonly encountered in veterinary practice. It is not clinically evident until the level of haemoglobin fall below $8 \mathrm{~g} / \mathrm{dl}$ (Ettinger and Feldman, 2005). Anemia is defined as the decreased ability of blood to supply tissues with adequate oxygen for proper metabolic functions (Jha et al., 2013). It is not a specific disease but the result of many diseases. These include blood loss, hemolysis and diseases that decrease the production of red blood cells. The main causes of anemia in dogs include trauma or injury that damages blood vessels or internal organs, parasites such as fleas, ticks and hookworms, tumors of the intestinal tract, kidneys and urinary bladder, diseases that prevent proper clotting of blood, blood parasites, chemicals or toxins, very poor nutrition or nutritional imbalances (Dhuria et al., 2013). Clinical signs of anemia result from decreased oxygen carrying capacity, reduced blood volume and underlying disease. Severity of clinical signs depends on the rapidity of onset, the degree and cause of anemia and the extent of physical activity (Ettinger and Feldman, 2005). The common clinical signs associated with anemia are pale mucous membranes, tachypnea, tachycardia, increased capillary refill time, lethargy and weakness, soft systolic heart murmur and weak peripheral pulse.

Specific types of anemia may represent icterus due to haemolysis, fever due to infectious, haemorrhages due to haemostatic problem and trauma, hepato-splenomegaly due to immune-mediated disease, neoplasia, infection and hypothyroidism (Ahn and Cottor, 1992). Haematological

How to cite this article: Tandel, F., Jani, R., Bilwal, A. and Vasava, P (2019). Etiopathology and haematobiochemical alteration in the anaemic dogs of in and around Anand region, Gujarat. J. Anim. Res., 9(6): 935-943. 
parameters are good indicators of physiological health status and its evaluation is important in assessing the response of animal to various physiological stressful conditions (Hindawy, 1950). Effective therapeutic management depends on better understanding of underlying etiopathology and alterations in haematobiochemical parameters. Very scanty reports are available for anemia specifically in canines. With this background present study was carried out in order to evaluate diagnostic significance of etiopathology and haematobiochemical parameters in naturally occurring anaemic dogs of Anand region of Gujarat state irrespective of their age, breed and sex.

\section{MATERIALS AND METHODS}

\section{Ethical approval}

Samples were collected from clinical cases coming to Teaching Veterinary Clinical Complex (TVCC), Veterinary College, Anand Agricultural University, Anand. So, this particular study did not require ethical approval.

\section{Study design}

The Research Committees of the Faculty of Veterinary Science, Anand Agricultural University, approved this study and written consent by the dog's owners was obtained. The present study was conducted at the Teaching Veterinary Clinical Service Complex of Veterinary College Anand during the period of May 2015 to December 2015. The canine population registered in Teaching Veterinary Clinical Service Complex of Veterinary College Anand covering 51 dogs of either sex of different age and breed groups with different disorders which exhibited anemic sign was study in detail and 16 dogs were kept as healthy control which were dewormed, vaccinated, and free from ectoparasites and were brought for health checkup.

\section{Sample collection}

$3 \mathrm{ml}$ of blood was withdrawn from cephalic vein, out of which $1 \mathrm{ml}$ was collected in a sterile plastic $\mathrm{K}_{3}$ EDTA vaccutainer for haematological analysis and $2 \mathrm{ml}$ in a sterile plain plastic vaccutainer which was centrifuged at 3000-3500 rpm for 5 minutes to separate serum and was stored at $4^{\circ} \mathrm{C}$ for further investigation. Stool collected directly from the rectum with the help of swab at the time of presentation to clinics.

\section{Analytical methods}

Haematological analysis was done by using an autohaematoanalyzer (Analytical, Hema-2062) include Haemoglobin ( $\mathrm{Hb})$, Total Erythrocyte Count (TEC), Total Leukocyte Count (TLC), Packed Cell Volume (PCV), Differential Leukocyte Count (DLC), Mean Corpuscle Volume (MCV), Mean Corpuscle Haemoglobin (MCH) and Mean Corpuscle Haemoglobin Concentration (MCHC). Serum biochemical parameters were analyzed by auto-chemistry analyzer (Mindray, BS-120 chemistry analyser) using commercial diagnostic kits procured from Crest Biosystem (A Division of Coral Clinical System, Goa) at Department of Veterinary Physiology \& Biochemistry, College of Veterinary Science \& Animal Husbandry, Anand with standard laboratory protocols. Blood smears were prepared as per the standard methods described by Kelly, 1979 stained with Giemsa stain and examined under oil immersion field in cases suspected for hemoprotozoan disease. Faecal samples were collected and examined as per the methods described by Soulsby, 1982 in cases with suspected involvement of endoparasites. Saline autoagglutination test was carried out for suspected immune mediated haemolytic anemia in dogs as per the methods described by Mackin, 2002.

\section{STATISTICAL ANALYSIS}

The data obtained were subjected to the statistical analysis described by Snedecor and Cochran, 1990. The t-test for paired samples having means with unequal variances was carried out. Variables with $\mathrm{p}<0.05$ were considered as statistically "significant," variables with $p<0.01$ were considered as statistically "highly significant" and variables with $\mathrm{p}>0.05$ were considered as statistically "non-significant."

\section{RESULTS AND DISCUSSION}

Total 78 dogs were screened, out of these 51 dogs positive for anemia diagnosed based on physiological as well as haematological parameters indicating 65.38 per cent incidence. Fifty one cases were studied in detailed 
including laboratory investigation which revealed different etiologies as below.

\section{Etiology}

Different etiologies of anemia in dog population under study are presented in table 1 .

Table 1: Different Etiological Agents of Anemia

\begin{tabular}{llcc}
\hline $\begin{array}{c}\text { Sl. } \\
\text { No. }\end{array}$ & \multicolumn{1}{c}{ Major diseases/disorders exhibiting } \\
anemia & $\begin{array}{c}\text { Number } \\
\text { of cases }\end{array}$ & $\begin{array}{c}\text { Per cent } \\
\mathbf{( \% )}\end{array}$ \\
\hline 1) & Liver disorders & 12 & 23.53 \\
2) & Parasitic diseases & 12 & 23.53 \\
1. Ancylostoma caninum & 09 & 17.65 \\
2. Dipylidium caninum & 02 & 03.92 \\
3. Toxocara caninum & 01 & 01.96 \\
3) & Renal disorders & 09 & 17.65 \\
4) Haemoprotozoon diseases & 09 & 17.65 \\
& 1. Babesia canis & 05 & 09.80 \\
2. Ehrlichia canis & 04 & 07.84 \\
5) Bacterial diseases (Pyometra, Enteritis, & 05 & 09.80 \\
& Gastroenteritis, Haemorrhagic & & \\
Gastroenteritis) & & \\
6) & Viral diseases (Haemorrhagic & 04 & 07.84 \\
Gastroenteritis) & & \\
\hline
\end{tabular}

(Singh et al., 2012) reported that prevalence of anemia in dogs due to digestive disorders $(30.76 \%)$ followed by ectoparasitic infestations $(9.23 \%)$, hepatic insufficiency $(9.23 \%)$, haemoprotozoan infection $(7.69 \%)$ and renal disorder $(1.57 \%)$. Similarly, anemia cause by gastro intestinal infection reported $40 \%$ by (Uppal et al., 2009) and $54.30 \%$ by (Katagiri and Oliveira-Sequeira, 2008) and haemoprotozoan infection (11.6\%), among that of Babesia gibsoni (84.9\%), Ehrlichia canis (6\%), Hepatazoan canis (4.8\%), Babesia canis $(3.9 \%)$ and Trypanasoma evansi (0.4\%) by Kumar et al. (2009).

\section{Vital signs of anemia}

Different vital manifestations of anemia were recorded in the presents study is presented in the table 2.
Table 2: Different vital signs in anemia

\begin{tabular}{lccc}
\hline \multicolumn{2}{c}{ Vital signs } & $\begin{array}{c}\text { No. of cases } \\
(\mathbf{N}=\mathbf{5 1})\end{array}$ & Percent (\%) \\
\hline Rectal Temperature & Hypothermia & 35 & 68.63 \\
$\left({ }^{\circ}\right.$ F) & Hyperthermia & 16 & 31.37 \\
Heart rate (beats/ & Bradycardia & 15 & 29.41 \\
min) & Tachycardia & 36 & 70.59 \\
Respiration rate & Bradypnoea & 13 & 25.49 \\
(breaths/min) & Tachypnoea & 38 & 74.51 \\
& Pale & 44 & 86.27 \\
Mucosal Membrane & Congested & 05 & 09.80 \\
& Icteric & 02 & 03.93 \\
Capillary refill time & $2-3$ & 18 & 35.29 \\
(sec) & $(>3)$ & 33 & 64.71 \\
\hline
\end{tabular}

The most anemic patients have pale mucous membranes, whereas icterus suggests acute hemolysis. A rough estimate is that the destruction of $4 \mathrm{~g}$ of hemoglobin in a 24 hour period may cause icterus even in the presence of normal liver function. Persisting icterus suggests hepatic or biliary disease. Petechial mucous membranes caused by thrombocytopenia may be due to hemolysis or blood loss from mucosal hemorrhages throughout the gastrointestinal tract (Ahn and Cotter, 1992). No such study have been documented in dogs with clinical sign of aneamia so could not compared with other findings.

Pale mucosal membrane of the present study was in agreement with report of (Searcy et al., 1971; Lobetti and Schoemana, 2001; Mali et al., 2006; Helens, 2008; Bhojne et al., 2013; Ghodasara et al., 2014). Hyperthermia was accordance with (Bhojne et al., 2013; Ghodasara et al., 2014). Tachycardia and Tachypnoea both were in agreement with report of (Lobetti and Schoemana, 2001).

\section{Age-wise etiology of Anemia}

Age-wise etiology of anemia in dog population under study is presented in table 3 .

Furthermore, within different age group, prevalence of anemia was observed with higher rate $(58.83 \%)$ in adult age group as compared to younger $(21.57 \%)$ and senile group (19.60\%). Amongst adult dogs renal disorders and Ancylostoma caninum infection were found predominantly higher with 23.33 per cent each. 
Table 3: Age-wise prevalence of anemia

\begin{tabular}{|c|c|c|c|c|}
\hline \multirow[b]{2}{*}{$\begin{array}{l}\text { Sl. } \\
\text { No. }\end{array}$} & \multirow[b]{2}{*}{ Etiology } & \multicolumn{3}{|c|}{ Age } \\
\hline & & $\begin{array}{c}\text { Young }(<6 \\
\text { month) }\end{array}$ & $\begin{array}{l}\text { Adult ( }>6 \\
\text { month to } \\
<8 \text { years) }\end{array}$ & $\begin{array}{c}\text { Senile }(>8 \\
\text { years) }\end{array}$ \\
\hline 1 & Liver disorder & 2 & 5 & 5 \\
\hline 2 & $\begin{array}{c}\text { Renal disorders } \\
\text { (Cystitis, Urolith, } \\
\text { Hematutia) }\end{array}$ & 0 & 7 & 2 \\
\hline 3 & Ancylostoma spp. & 2 & 7 & 0 \\
\hline 4 & Babesia spp. & 3 & 1 & 1 \\
\hline 5 & H. Gastroenteritis & 2 & 3 & 0 \\
\hline 6 & Ehrlichia spp. & 0 & 4 & 0 \\
\hline 7 & Gastroenteritis & 1 & 1 & 0 \\
\hline 8 & Pyometra & 0 & 0 & 2 \\
\hline 9 & Dipylidium caninum & 1 & 1 & 0 \\
\hline \multirow[t]{2}{*}{10} & Toxocara canis & 0 & 1 & 0 \\
\hline & Total (\%) & $11(21.57)$ & $30(58.83)$ & $10(19.60)$ \\
\hline
\end{tabular}

(Singh et al., 2012) reported that anemia in dogs below 6 months followed by 6 month to 1 year, 1 to 3 year and 6 to 10 year age groups were $44.61 \%, 15.38 \%, 20 \%$ and $44.61 \%$ respectively. (Kumar et al., 2014) reported that anemia due to Toxocara canis infestation within different age group 0-1 month, 1-3 months, $>3$ month of age were $31.82 \%, 55.56 \%$ and $18.06 \%$ respectively. However, due to haemoprotozoan infection (11.6\%) among that highest percentage observed in adults (63.1\%) (Kumar et al., 2014 ) and due to canine babesiosis (6.93\%) with $15.38 \%$ were under 1 year age, $20.19 \%$ of $1-3$ year age and $64.42 \%$ of more than 3 years age (Shrivastava and Shukla, 2013). This observation reveal infection was recorded more in adult than young ones.

\section{Sex-wise etiology of Anemia}

The sex-wise prevalence of anemia in dog population under study is presented in table 4 .

Prevalence of anemia was observed higher in male $(52.94 \%)$ than in female dogs $(47.60 \%)$. Liver $(33.30 \%)$ and renal (29.16\%) disorders were major etiological factor emerged out amongst male and female dogs in present study. However Ancylostoma spp. was found second leading etiology in male dogs. Reports suggest that there is no correlation between incidence of anemia and sex of dogs (Huxsoll et al., 1972).
Table 4: Sex-wise etiology of anemia

\begin{tabular}{|c|c|c|c|c|}
\hline $\begin{array}{l}\text { SI. } \\
\text { No. }\end{array}$ & Etiology & Male & Female & Total \\
\hline 1 & Liver disorder & 9 & 3 & 12 \\
\hline 2 & $\begin{array}{l}\text { Renal disorders (Cystitis, } \\
\text { Urolith, Hematutia) }\end{array}$ & 2 & 7 & 09 \\
\hline 3 & Ancylostoma spp. & 6 & 3 & 09 \\
\hline 4 & Babesia spp. & 3 & 2 & 05 \\
\hline 5 & H. Gastroenteritis & 1 & 4 & 05 \\
\hline 6 & Ehrlichia spp. & 3 & 1 & 04 \\
\hline 8 & Gastroenteritis & 1 & 1 & 02 \\
\hline 9 & Pyometra & 0 & 2 & 02 \\
\hline 7 & Dipylidium spp. & 1 & 1 & 02 \\
\hline 10 & Toxocaraspp. & 1 & 0 & 01 \\
\hline & Total (\%) & $\begin{array}{c}27 \\
(52.94 \%) \\
\end{array}$ & $\begin{array}{c}24 \\
(47.60 \%) \\
\end{array}$ & $\begin{array}{c}51 \\
(100 \%) \\
\end{array}$ \\
\hline
\end{tabular}

However, anemia due ancylostomiasis was highest in adult male dogs $(42.30 \%)$ as compared to adult females $(34.10 \%)$ and dipylidiasis was highest in adult female dogs $(03.10 \%)$ as compared to adult males $(01.80 \%)$ (Katagiri and Oliveira-Sequeira, 2008).

\section{Breed wise Prevalence}

The breed-wise prevalence of anemia presented in table 5 revealed high prevalence in Labrador (35.29\%) followed by ND $(19.60 \%)$, German shepherd and Doberman (13.73\% each) (Table 5).

However, in other breeds major etiologies were not evident equally due to small population of dogs presented from these breeds. The variation of breed predisposition could be due to preference of pet owners for selection of breeds as their pets (Singh et al., 2012). To the authors' knowledge there are no reports on breed-disposition to occurrence of anemia for breeds involved in the study.

\section{Haematological profile}

To evaluate the haematological indicators in dogs positive for naturally occurring anemia in comparison with normal healthy dogs is presented in table 6 .

Decreased $\mathrm{Hb}$ level of the present study was in agreement with report of (Emily et al., 1925; Lobetti and Schoemana, 2001; Machado et al., 2002; Castro et al., 2004; Mali et al., 2006, Niwetpathomwat et al., 2006; Ogunkoya et al., 
Table 5: Breed-wise prevalence of anemia

\begin{tabular}{|c|c|c|c|c|c|c|c|c|c|c|}
\hline $\begin{array}{l}\text { SI. } \\
\text { No. }\end{array}$ & Etiology & Lab & GSD & $\begin{array}{l}\text { Doberman } \\
\text { Pinscher }\end{array}$ & Spitz & Beagle & Boxer & Pug & ND & Total \\
\hline 1 & Liver disorder & 7 & 2 & 1 & 0 & 0 & 0 & 0 & 2 & 12 \\
\hline 2 & $\begin{array}{l}\text { Renal disorders (Cystitis, } \\
\text { Urolith, Hematutia) }\end{array}$ & 2 & 2 & 1 & 1 & 0 & 0 & 0 & 3 & 09 \\
\hline 3 & Ancylostoma spp. & 2 & 0 & 2 & 2 & 1 & 1 & 0 & 1 & 09 \\
\hline 4 & Babesia spp. & 3 & 2 & 0 & 0 & 0 & 0 & 0 & 0 & 05 \\
\hline 5 & H. Gastroenteritis & 2 & 0 & 1 & 1 & 0 & 0 & 0 & 1 & 05 \\
\hline 6 & Ehrlichia spp. & 1 & 1 & 1 & 0 & 0 & 0 & 0 & 1 & 04 \\
\hline 7 & Gastroenteritis & 0 & 0 & 1 & 0 & 0 & 0 & 1 & 0 & 02 \\
\hline 8 & Pyometra & 0 & 0 & 0 & 1 & 0 & 0 & 0 & 1 & 02 \\
\hline 9 & Dipylidium spp. & 1 & 0 & 1 & 0 & 0 & 0 & 0 & 0 & 02 \\
\hline \multirow[t]{2}{*}{10} & Toxocara spp. & 0 & 0 & 0 & 0 & 0 & 0 & 0 & 1 & 01 \\
\hline & Total (\%) & $18(35.29)$ & $7(13.73)$ & $7(13.73)$ & $5(5.80)$ & 1 (1.96) & 1 (1.96) & $1(1.96)$ & $10(19.60)$ & $51(100)$ \\
\hline
\end{tabular}

Table 6: Haematological Profile of Anemic and Healthy Dogs (Mean \pm SE)

\begin{tabular}{ccc}
\hline Parameter & Healthy group (N=16) & Affected group (N=51) \\
\hline $\mathrm{Hb}(\mathrm{g} / \mathrm{dl})$ & $14.09 \pm 0.24$ & $07.98 \pm 00.06^{* *}$ \\
$\mathrm{TEC}\left(\times 10^{6 / \mu \mathrm{l})}\right.$ & $06.95 \pm 00.07$ & $04.21 \pm 00.16^{* *}$ \\
$\mathrm{TLC}\left(\times 10^{3} / \mu \mathrm{l}\right)$ & $12.83 \pm 01.03$ & $15.50 \pm 00.06^{*}$ \\
Neutrophils $(\%)$ & $67.56 \pm 01.76$ & $66.68 \pm 00.05$ \\
Lymphocytes (\%) & $28.75 \pm 00.35$ & $29.72 \pm 00.20$ \\
Monocytes (\%) & $02.25 \pm 00.17$ & $01.86 \pm 00.10$ \\
Eosinophils (\%) & $01.43 \pm 00.18$ & $01.84 \pm 00.10$ \\
Basophils (\%) & $00.00 \pm 00.00$ & $00.16 \pm 00.00$ \\
Platelet count ( $\left.\times 10^{5} / \mu \mathrm{l}\right)$ & $239.56 \pm 10.96$ & $255.38 \pm 03.27$ \\
PCV $(\%)$ & $41.4 \pm 00.70$ & $23.02 \pm 00.10^{* *}$ \\
$\mathrm{MCV}(\mathrm{fl})$ & $64.86 \pm 00.72$ & $50.56 \pm 00.30^{* *}$ \\
$\mathrm{MCHC}(\mathrm{g} / \mathrm{dl})$ & $32.03 \pm 00.38$ & $28.82 \pm 00.69^{* *}$ \\
$\mathrm{MCH}(\mathrm{pg})$ & $21.82 \pm 00.53$ & $17.49 \pm 00.35^{* *}$ \\
\hline
\end{tabular}

2006; Helens, 2008; Kohn et al., 2008; Gunseelan et al., 2009; Turkar et al., 2009; Sharma et al., 2010; Qadir et al., 2011; Sarma et al., 2011; Shah et al., 2011; Wadhwa et al., 2011; Andoni et al., 2012; Dixit et al., 2012; Srikala et al., 2012; Bhardwaj, 2013; Bhojane et al., 2013; Das and Konar, 2013 and Reddy et al., 2014).

TEC level was decreased in accordance with (Oliveira, 2000; Machado, 2002; Castro et al., 2004; Helens, 2008; Chattha et al., 2009; Gunseelan et al., 2009; Turkar et al., 2009; Qadir et al., 2011; Sarma et al., 2011; Andoni et al., 2012; Das and Konar, 2013 and Nalubamba et al., 2015).

Decrease in PCV levels were in agreement with reports of
(Emily et al., 1925; Searcy et al., 1971; Dickson, 2006; Helens, 2008; Carrade et al., 2009; Gunseelan et al., 2009; Sharma et al., 2010; Sarma et al., 2011; Das and Konar, 2013; Dhuria et al., 2013 and Kumar et al., 2014). Haemoglobin concentration as a third part of packed cell volume or vice-versa. Whereas, total erythrocyte count as a sixth part of packed cell volume or vice-versa. $\mathrm{Hb}$ concentration, PCV and TEC are dependent in each other. They are closely related with each other. So, when one parameter affected, they affects other two parameters also. That's why in anaemic case, decreased $\mathrm{Hb}$ concentrate also decreased TEC and PCV (Ettinger and Feldman, 2005). 
Increased TLC level of the present study was in agreement with report of (Helens, 2008; Sharma et al., 2010; Bhardwaj, 2013; Chhabra et al., 2013 and Das and Konar, 2013) which were contrast to (Irwin, 2007; Nakaghi et al., 2008 and Selvaraj et al., 2010) whose reported presence of significant leucopenia in dogs with anemia.

The difference between DLC in dogs with anaemic and healthy dogs was statistically non-significant (Selvaraj et al., 2010; Shah et al., 2011; Chhabra et al., 2013; Das and Konar, 2013) reported significant increase in neutrophils (\%) in dogs with anemia.

However, (Dixit et al., 2012; Reddy et al., 2014) reported decreased count of neutrophils in dogs with anemia (Dixit et al., 2012 and Reddy et al., 2014) reported significant increase in lymphocytes count in dogs with anemia. However, (Oliveira, 2000; Andoni et al., 2012; Bilwal et al., 2017) reported significant decrease in lymphocytes in dogs with anemia. Castro et al., 2004 and Srikala et al., 2012 were agreement with levels of eosinophils decreased significantly. Castro et al., 2004 reported significant increase in levels of monocytes. However, Oliveira, 2000 recorded significant decrease in levels of monocytes in dogs with anemia. Any DLC values which increase or decrease are depend upon the etiology of anemia. In case of bacterial infection with anemia showed neutrophilia where lymphocytosis may be due to viral infection. Moreover, eosinophil was increased due to parasitic infection.

Among RBC indices, values of MCV (fl), MCHC (g/ dl) and $\mathrm{MCH}(\mathrm{pg})$ decreased significantly in dogs with anemia than healthy dogs. Decrease in MCHC levels were in agreement with reports of (Castro et al., 2004 and Helens, 2008). However, (Bhadesiya and Raval, 2015) reported increased MCHC level in affected dogs. (Mulla, 2007) recorded significant $(\mathrm{P}<0.05)$ decrease in levels of MCH in dogs with anemia. However, (Emily et al., 1925) observed severe anemia case with normal MCV and MCHC. The RBC indices measure the size, shape and physical characteristics of the RBCs. Anemia is a common blood disorder in which will have too few, misshapen or poorly functional RBCs. RBC indices and RBC count are used to diagnose different types of anemia. The MCV will be lower than normal when red blood cells are too small called as microcytic anemia. If the $\mathrm{MCHC}$ value is low, it means relative hemoglobin concentration per unit volume of red blood cell is low called as hypochromic. Anemia in which both MCV and MCHC are low called as microcytic hypochromic anemia and this condition caused by iron deficiency or chronic diseases. $\mathrm{MCH}$ is the average amount of Haemoglobin per red blood cells (Benjamin, 2001).

The difference between platelet count in dogs with aneamia and healthy were statistically non-significant. (Marion et al., 1985; Dickson, 2006; Carrade et al., 2009; Turkar et al., 2009; Shah et al., 2011; Das and Konar, 2013; Gaudarrama-Olhovich et al., 2013; Ghodasara et al., 2014 and Vishnurahav et al., 2014) and who reported significant decreased platelet counts (i.e. thrombocytopenia) which were contrast to (Lionel et al., 2014) who reported significant increased platelet counts (i.e. thrombocytosis).

\section{Blood Biochemical Profile}

To evaluate the biochemical indicators in dogs positive for naturally occurring anemia in comparison with normal healthy dogs is given in Table 7.

Table 7: Blood Biochemical Profile of Anemic and Healthy Dogs (Mean \pm SE)

\begin{tabular}{ccc}
\hline Parameter & $\begin{array}{c}\text { Healthy group } \\
(\mathbf{N = 1 6})\end{array}$ & $\begin{array}{c}\text { Affected group } \\
(\mathbf{N}=\mathbf{5 1})\end{array}$ \\
\hline ALT $(\mathrm{IU} / \mathrm{L})$ & $37.33 \pm 00.78$ & $70.56 \pm 01.18^{* *}$ \\
AST $(\mathrm{IU} / \mathrm{L})$ & $43.18 \pm 02.81$ & $71.23 \pm 00.07^{* *}$ \\
$\mathrm{TPP}(\mathrm{g} / \mathrm{dl})$ & $06.27 \pm 00.25$ & $05.31 \pm 00.17$ \\
A:G(gm/dl) & $01.10 \pm 00.07$ & $01.08 \pm 00.03$ \\
Glucose(mg/dl) & $88.35 \pm 02.59$ & $118.46 \pm 06.39^{* *}$ \\
BUN (mg/dl) & $13.50 \pm 01.05$ & $22.74 \pm 03.93^{* *}$ \\
SCr $(\mathrm{mg} / \mathrm{dl})$ & $01.19 \pm 00.19$ & $02.74 \pm 00.74^{* *}$ \\
\hline
\end{tabular}

Levels of AST and ALT increased significantly in dogs with anemia than healthy dogs. These findings were in accordance with (Castro et al., 2004; Helens, 2008; Sharma et al., 2010; Gaudarrama-Olhovich et al., 2013; Ghodasara et al., 2014; Bilwal et al., 2017 and Bilwal et al., 2018) whereas, (Turkar et al., 2009) reported normal level of AST in anaemic dogs. Increased ALT and AST may be attributed to the hemolysis and cellular damage to the hepatic cells (Shrivastava et al., 2014). It may due to hepatocellular degeneration (Guadarrama-Olhovich et al., 2013) or hepatic dysfunction (Niwetpathomwat et al., 2005).

Decreased TPP level of the present study was in agreement with report of (Helens, 2008; Turkar et al., 2009; Sharma 
et al., 2010; Sarma et al., 2011; Gaudarrama-Olhovich et al., 2013; Khatat et al., 2015 and Bilwal et al., 2017). Hypoproteinaemia due to hypoalbuminaemia was caused by decreased intake and chronic inflammation (Gaudarrama-Olhovich et al., 2013). Hepatic dysfunction leads to hypoproteinemia in dogs with anemia (Agnihotri et al., 2012).

Level of Glucose increased significantly $(\mathrm{P}<0.01)$ in dogs with anemia than healthy dogs which were contrast to (Sharma et al., 2010; Sarma et al., 2011 and Shrivastava et al., 2014) whose reported significant decreased glucose level in dogs with anemia than healthy dogs. The hepatocyte actively stores glucose by converting it to glycogen. Glycogen can then be later broken down into general circulation. This function regulated by insulin hormone. In liver disease or liver dysfunction case, dogs become hyperglycemic because hepatocyte cannot store glucose while, as dietary intake is decreased or absent, the hepatocyte are not able to mobilize glucose from what little stored glycogen, so such dogs will have episodes of hypoglycemia.

Levels of BUN increased significantly $(\mathrm{P}<0.01)$ in dogs with anemia than healthy dogs. These results were in accordance with (Ghodasara et al., 2014 and Khatat et al., 2015) whereas, (Sarma et al., 2011 and Shrivastava et al., 2014) decreased BUN level in dog with anemia. Creatinine level was increased in accordance with (Sarma et al., 2011 and Khatat et al., 2015). However, (Shrivastava et al., 2014) reported decreased Creatinine level. Increase in creatinine and BUN levels may be due to glomerulonephritis indicating renal involvement in dogs with anemia.

\section{ACKNOWLEDGMENTS}

This study was funded by College of Veterinary Science and Animal Husbandry, Anand Agricultural University, Anand, Gujarat. Authors are thankful to the staff of TVCC and the Department of Veterinary Physiology and Biochemistry at College of Veterinary Science and Animal Husbandry, Anand Agricultural University, Anand, Gujarat, as well as dog owners of different areas for their valuable cooperation.

\section{REFERENCES}

Agnihotri, D., Khurana, R., Jain, V.K. and Singh, G. 2012. Concurrent infection of Ehrlichia canis and Ancylostomosis in a dog. Indian Vet. J., 89(11): 89-90.

Ahn, A. and Cotter, S.M. 1992. Approach to the anemic patient. In: Current Veterinary Therapy XII. WB Saunders, Philadelphia, pp. 25-38.

Andoni, E., Rapti, D., Postoli, R. and Zalla, P. 2012. Hematologic changes in dogs naturally infected with Babesia. Albanian $J$. Agric. Sci., 11: 3 .

Benjamin, M.M. 2001. In: Outline of veterinary clinical pathology. $3^{\text {rd }}$ Edn., Kalyani Publishers, New Delhi, pp. 351.

Bhadesiya, C.M. and Raval, S.K. 2015. Hematobiochemical changes in ehrlichiosis in dogs of Anand region, Gujarat. Vet. World, 8(6): 713-717.

Bhardwaj, R.K. 2013. Therapeutic management of acute canine monocytic ehrlichiosis. Indian Vet. J., 90(2): 138-139.

Bhojne, G.R., Dakshinkar, N.P., Sanghai, A.A. and Dubey, A.G. 2013. Canine Babesiosis- A Case Study. Ind. J. Can. Pract., 5(2): 117-118.

Bilwal, A.K. Mandali, G.C. and Tandel, F.B. 2017. Clinicopathological alterations in naturally occurring Babesia gibsoni infection in dogs of middle-south Gujarat, India. Veterinary World, 10(10): 1227-1232.

Bilwal, A.K; Mandali, G.C and Tandel, F.B. 2018. Liver Enzyme activity in Dogs infected with Babesia canis. Intas Polivet., 19(2): 313-314.

Carrade, D.D., Foley, J.E., Borjesson, D.L. and Sykes, J.E. 2009. Canine Granulocytic Anaplasmosis: A Review. J. Vet. Intern. Med., 23: 1129-1141.

Castro, D.B.M., Machado, R.Z., Tomaz de Aquino, L.P.C., Alessi, A.C. and Costa, M.T. 2004. Experimental acute canine monocytic ehrlichiosis: Clinicopathological and immunopathological findings. Vet. Parasitol., 119: 73-86.

Chattha, M.A., Aslam, A., Rehman, Z.U., Khan, J.A. and Avais, M. 2009. Prevalence of Toxocara canis infection in dogs and its effects on various blood parameters in Lahore (Pakistan). J. Anim. Plant Sci., 19: 71-73.

Chhabra, S., Uppal, S.K. and Singla, L.D. 2013. Retrospective study of clinical and hematological aspects associated with dogs naturally infected by Hepatozoon canis in Ludhiana, Punjab, India. Asian Pac J. Trop. Biomed., 3(6): 483-486.

Das, M. and Konar, S. 2013. Clinical and hematological study of canine Ehrlichiosis with other hemoprotozoan parasites in Kolkata, West Bengal, India. Asian Pac. J. Trop. Biomed., 3(11): 913-915. 
Dhuria, D., Meena, D.S., Shrivastav, S.M., Ahuja, A. and Bihani, D.K. 2013. Prevalence of Anemia in dogs in and around Bikaner Region of Rajasthan. Vet. Immunol. Immunopathol., 15(1): 139.

Dickson J. 2006. Autoimmune hemolytic anemia success stories. C.F. http://www.cloudnet.com/ jdickson/successstories.htm. 1 to 3 .

Dixit, A.K., Dixit, P. and Sukla, P.C. 2012. Canine monocytic ehrlichiosis and its therapeutic management in a dog. Intas. Polivet., 13(1): 140-141.

El Hindawy, M.R. 1950. Studies on the blood of dogs IV.Haematological finding in the dogs suffering from some common disease. Brit. Vet. J., 106: 119-127.

Emily, M.P., Mamoru, Y., Maxey, L., Wellman, M. and Judith, R. 1925. Platelet vacuoles in a dog with severe non regenerative anemia: evidence of platelet autophagy. J. Am. Anim. Hosp. Assoc., 5(4): 5-44.

Ettinger, S.J. and Feldman, E.C. 2005. Haematology and Immunology - Regenerative anaemia caused by blood loss or haemolysis. In: Textbook of Veterinary Internal Medicine. Pub. Elsevier Health Sciences, 1(6): 1886-1907.

Ghodasara, S.N., Fefar, D.T., Savsani, H.H., Bhadaniya, A.R. and Kalaria, V.A. 2014. Haemato-biochemical profile and therapeutic management of ehrlichiosis in germen shepherd dogs. Intas Polivet., 15(1): 165-167.

Guadarrama-Olhovich, M., Garcia Ortuno, L.E., Ruiz Remolina, J.A., Lopez Buitrago, C. and Ramirez, L.J. 2013. Acute pancreatitis, azotaemia, cholestasis and haemolytic anaemia in a dog. Vet. Med., 58(1): 44-49.

Gunaseelan, L., Kumar, K.S., Selvaraj, P. and Kathiresan, D. 2009. Haemato biochemical changes in a case of canine trypanosomiasis. Tamil Nadu J. Vet. Anim. Sci., 5(3): 122123.

Helens, S. 2008. Anaemia caused by Gastrointestinal Haemorrhage in a Dog. C.F. www.AxiomVetlab.com., 1-2.

Huxsoll, D.L., Amyx, H.L., Hemelt, I.E., Hildebrandt, P.K., Nims, R.M. and Gochenour, W.S. 1972. Laboratory studies of tropical canine pancytopenia. Exp. Parasitol., 31(1): 5359.

Irwin, P.J. 2007. Pups, PCRs and Platelets: ehrlichia and anaplasma infections of dogs in Australia and overseas, Proceedings of the World Small Animal Veterinary Association, Sydney, Australia.

Jha, K.K., Das, A.K., Sinha, S., Shekhar, P and Kumar, B. 2013. Effect of alternative methods of blood Transfusion on haematological parameters in Anaemic dogs. Indian Journal of Canine Practice, 5(1): 114-116.

Katagiri, S. and Oliveira-Sequeira, T.C.G. 2008. Prevalence of dog intestinal parasites and risk perception of zoonotic infection by dog owners in Sao Paulo State, Brazil. Zoonoses and Pub. Health, 55: 406-413.

Kelly, W.R. 1979. The Blood and Blood-forming Organs. In: Veterinary Clinical Diagnosis. Pub. Tindall \& Cassell, $2^{\text {nd }}$ Edition, pp. 267.

Khatat, S.E., Defauw, P., Marynissen, S., Van de Maele, I., Van Dongen, A. and Daminet, S. 2015. Exposure to Anaplasma phagocytophilum in two dogs in Belgium. Vlaams Diergenceskundig Tijdschrift, 84: 39-46.

Kohn, B., Galke, D. and Beelitz, P. 2008. Clinical features of canine granulocytic anaplasmosis in 18 naturally infected dogs. J. Vet. Intern. Med., 22: 1289-1295.

Kumar, K.S., Vairamuthu, S. and Kathiresan, D. 2009. Prevalence of haemoprotozoans in canines in chennai city. Tamil Nadu J. Vet. Anim. Sci., 5(3): 104-108.

Kumar, M., Sharma, B., Kumar, A., Lal, H.P., Kumar, V. and Tripathi, M.K. 2014. Prevalence and Haemato-Biochemical Studies of Toxocara canis Infestation in Dogs and Risk of Zoonoses by Dog Owners in Mathura, India. Asian J. Anim. Vet. Adv, 9(10): 653-663.

Lionel, S., Kenneth, R.H., Allison, H., Gumber, S. and Tiffany L. 2014. Irondeficiency anemia. J. American Anim. Hospital Assoc., 50(5): 350-355.

Lobetti, R.G. and Schoemana, T. 2001. Immune mediated haemolytic anaemia: possible association with Ancylostoma caninum infection in three dogs. J. S. Afr. Vet. Assoc., 72(1): $52-54$.

Machado, R.Z., Alessi, A.C., Santana, A.E., Castro, M.B., Marques, L.C. and Malheiros, E.B. 2002. Hematological, biochemical and anatomopathological aspects of the experimental infection with Trypanosoma evansi in dogs. Arq. Bras. Med. Vet. Zootec., 54: 1.

Mackin, A. 2002. Immune-mediated hemolytic anemia: Pathophysiology and diagnosis. Proc. ACVIM., 1-4.

Mali, H.V., Gangurde, K.C., Keskar, D.V. and Gaikwad, R.V. 2006. Study of Auto-Immune Hemolytic Anemia (AIHA) in Dog. J. Bombay Vet. Coll., 14(1\&2): 135.

Marion, L., Jackson and Stephen, A.K. 1985. Immune-mediated Hemolytic Anemia and Thrombocytopenia in the Dog: A retrospective study of 55 cases diagnosed from 1969 through 1983 at the Western College of Veterinary Medicine. Can. Vet. J., 26: 245-250.

Mulla, F. 2007. Scintigraphic study of doxycycline nanoparticulate in rabbits and assessing its efficacy in canine ehrlichiosis, M.V.Sc. Thesis submitted to Maharashtra Animal and Fishery Sciences University, Nagpur.

Nakaghi, A.C.H., Machado, R.Z., Costa, M.T., Andre, M.R. and Baldani, C.D. 2008. Canine ehrlichiosis: Clinical, 
haematological, serological and molecular aspects. Ciencia Rural - Santa Maria, 38(3): 766-770.

Nalubamba, K.S., Mudenda, N.B., Namwila, M.M., Mulenga, C.S., Bwalya, E.C., Kandawire, E.M., Saasa, N., Hancanga, C., Oparaocha, E. and Simuunza, M. 2015. A study of naturally acquired canine babesiosis caused by single and mixed Babesia species in Zambia: Clinicopathological findings and case management. Journal of Parasitology Research, Article ID 985015, 9 pages.

Niwetpathomwat, A., Techangamsuwan, S. and Suvamavibhaja, S. 2005. A retrospective study of the clinical hematology and biochemistry of canine ehrlichiosis in an animal hospital population in Bangkok, Thailand. J. Clin. Pathol., 14: 217220.

Niwetpathomwat, A., Somporn, L., Suvarnavibhaja, S. and Assarasakorn, S. 2006. A retrospective study of clinical hematology and biochemistry of canine babesiosis on hospital populations in Bangkok, Thailand. Comparative Clinical Pathology, 15(2): 110-112.

Ogunkoya, A.B., Esievo, K.A.N and Useh, N.M. 2006. The haemogram of dogs with gastrointestinal parasites in Zaria, Nigeria. J. Anim. Adv., 5: 782-785.

Oliveira, D. 2000. Ehrlichia canis antibodies detection by "DotELISA" in naturally infected dogs. Rev. Braz. Parasitol. Vet., 9(1): 1-5.

Qadir, S., Dixit, A.K., Dixit, P. and Sharma, R.L. 2011. Intestinal helminths include haematological changes in dogs from Jabalpur, India. J. Helminthol., 85: 401-403.

Reddy, B.S., Sivajothi, S., Reddy, L.S.S.V. and Raju, K.G.S. 2014. Clinical and laboratory findings of Babesia infection in dogs. J. Parasit. Dis. (DOI: 10.1007/s12639-014-0491-x).

Sarma, K., Saravanam, M., Kumar, M., Dar, A.A., Kumar, A., Jadhav, R.K. and Mondal, D.B. 2011. Trypanosomiasis in dog: A case report. Indian J. Vet. Med., 31(2): 124-125.

Searcy, G.P., Miller, D.R. and Tasker, J.B. 1971. Congenital Hemolytic Anemia in the Basenji Dog Due to Erythrocyte Pyruvate Kinase Deficiency. Can. J. comp. Med., 35: 67-70.

Selvaraj, P., Kumar, K.S., Vairamuthu, S., Prathaban, S. and Srinivasan, S.R. 2010. Babesia gibsoni - An emerging challenge in canine pediatric practice in Chennai. Tamil Nadu J. Vet. Anim. Sci., 6(3): 122-124.
Shah, S.A., Sood, N. and Tumati, S.R. 2011. Haematobiochemical changes in natural cases of canine babesiosis. Asian J. Ani. Sci., 5(6): 387-392.

Sharma, S.K., Sinha, S.R.P., Sinha, S., Jayachandram, C. and Kumar, M. 2010. Post-treatment haematological studies on toxocariasis in dogs. J. Vet. Parasito., 24: 63-65.

Shrivastava, S. and Shukla, P.C. 2013. Prevalence of canine babesiosis in dogs at and around Jabalpur (M.P.). BIOINFOLET, 10(3A): 905-906.

Shrivastava, S., Shukla, P.C. and Rao, M.L.V. 2014. An epidemiological study on canine hemoprotozoa in jabalpur (Madhya pradesh). Int. J. Agric. Sc. \& Vet. Med., 2(4): 34-40.

Singh, R., Ravjoyt, S., Beigh, S.A. and. Bhardwaj, R.K. 2012. Prevalence of Anaemia in Dogs from Jammu Region. Ind. J. Can. Prac., 4(1): 1-3.

Snedecor, G.W. and Cochran, W.G. 1990. Statistical Methods, $6^{\text {th }}$ Edition.Oxford and JBH Publishing, New York.

Soulsby, E.J.L. 1982. Helminths, arthropods and protozoa of domesticated animals. $7^{\text {th }}$ Edition. Baillere Tindall, London.

Srikala, D., Satish Kumar, K., Amruth Kumar, V.V.V. and Tirumala Rao, D.S. 2012. Clinical andtherapeutic aspects of canine monocyticehrlichiosis. Ind. J. Vet. Med., 32(2): 109110.

Turkar, S., Randhawa, C.S. and Uppal, S.K. 2009. Ascites associated with ancylostomiasis in a pup - a case report. Intas Polivet, 10(2): 357-359.

Uppal, S.K., Randhawa, C.S. and Dua, K. 2009. Clinicohaemato biochemical alteration in aneamicdogs. Proc $27^{\text {th }}$ international summit on "Advancing Veterinary Medical Care: Challeneges and strategies, TANVUS, Chennai-7, pp 272.

Vishnurahav, R.B., Pillai, U.N., Alex, P.C., Ajitkumar, S. and Lusysabu 2014. Haemato-biochemical changes in canine babesiosis. Indian Journal of Canine Practice, 6: 2.

Wadhwa, D.R., Pal, B., Mandial, R.K., Kumar, A. and Agnihotri, R.K. 2011. Clinical, haemato-biochemical and therapeutic studies of canine babesiosis in kangra valley of Himachal Pradesh. J. Vet. Parasitol., 25(1): 39-41. 
